原 著論 文

\title{
ノンクラスプデンチャーにおけるレストの有無が 義歯床下粘膜の負担圧分布に及ぼす影響
}

\section{廣田 正嗣, 新保 秀仁, 鈴木 恭典, 大久保 力廣 \\ Influence of Metal Rest in a Non-metal Clasp Denture on Pressure Distribution to Soft Tissue}

\author{
Masatsugu Hirota, DMD, Hidemasa Shimpo, DMD, PhD, \\ Yasunori Suzuki, DMD, PhD and Chikahiro Ohkubo, DMD, PhD
}

\section{抄 録}

目的：ノンクラスプデンチャーは特異的弾性を有することから, 金属維持装置を必要とせず, 広く臨床応 用されつつある。しかしながら，審美性を優先した設計が先行しており，レストを設置しないメタルレス の設計も行われている。本研究は，ノンクラスプデンチャーにおける金属レストの有無が義歯床下粘膜の 負担圧分布に及ぼす影響について検討を行った。

方法：下顎片側性中間欠損を想定したシミュレーション模型に三つの圧力センサーを設置した。実験義歯 は, 金属レスト付きノンクラスプデンチャー,レストも熱可塑性樹脂で製作したノンクラスプデンチャー, レストを設置しないノンクラスプデンチャーの 3 種とし，コントロールとして，金属レスト付きアクリ ルレジン床義歯，コバルトクロム製金属構造義歯の 2 種を製作した。擬似粘膜としてシリコーン印象材 を介在させ， $49.0 \mathrm{~N}$ の荷重を加えた時の義歯床下粘膜の負担圧分布を測定した。得られたデータ $(\mathrm{n}=5)$ は一元配置分散分析後, Tukey の多重比較検定（危険率 1\%）を行った.

結果：5 種実験義歯のなかでは，金属構造義歯の負担圧は有意に小さく，レストも熱可塑性樹脂で製作し たノンクラスプデンチャーが最も大きい值を示した。また，ノンクラスプデンチャーであっても金属レス トを付与することによって負担圧が軽減された $(\mathrm{p}<0.01)$.

結論：ノンクラスプデンチャーにおいて義歯床下粘膜の負担圧軽減には，金属レストの設置が必要である ことが示唆された。

和文キーワード

ハンクラスプデンチャー，熱可塑性合成樹脂，負担圧分布，レスト，金属構造義歯

\section{I . 緒 言}

欠損補綴の歴史は, 人類が口腔の審美を追い求めた歴 史といってもよいのではないだろうか.わが国における 義歯のはじまりは木床義歯とされるが，当時の義歯は機 能回復というよりはむしろ審美回復が主目的であったよ うに思われる ${ }^{1)}$ 。近年は，残存諸組織の保全を念頭にお いた補綴治療が行われるようになってきたが，患者の審 美への追求は現代社会においても高まるばかりである.
昨今, ノンクラスプデンチャーと呼称される熱可塑性 合成樹脂を応用した新たな義歯が，急速に臨床応用され ている. 熱可塑性合成樹脂は特異的弾性を有することか ら破折強度に優れ，従来型のメタルクラスプなどの金属 維持装置を必要としない. 熱可塑性合成樹脂製の維持装 置，すなわちフィンガーやループと呼ばれている構成要 素は，義歯床から同一の材料で製作されているため，歯 肉と自然に調和し審美性が高い。一方，メタルレスの利 点は，金属アレルギーを有する患者にも有効なことに加 え，技工操作が単純なことや軽量で適合精度が高いとい

鶴見大学歯学部有床義歯補綴学講座

Department of Removable Prosthodontics, Tsurumi University School of Dental Medicine 受付: 2011 年 6 月 13 日/受理 : 2011 年 11 月 8 日

Received on June 13, 2011/Accepted on November 8, 2011 


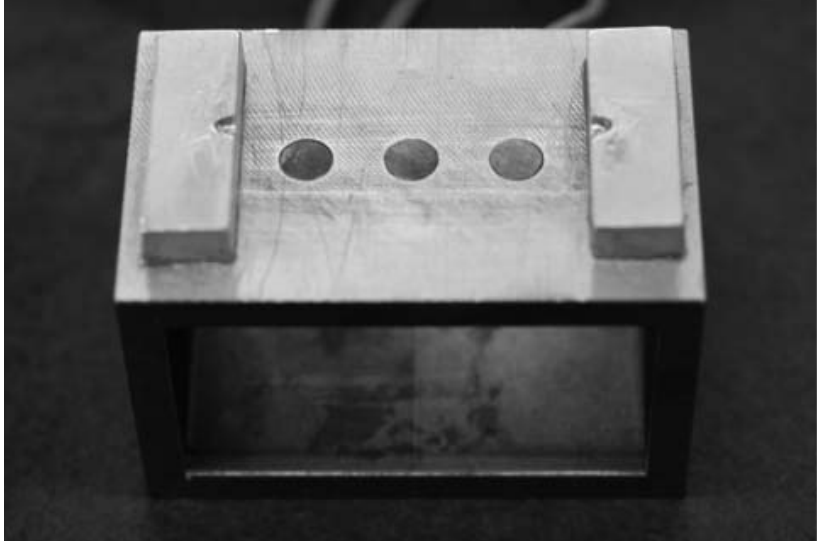

図 1 The simulation model シミュレーション模型

う報告もあり，ノンクラスプデンチャーは新たな補綴装 置の選択肢として注目されている ${ }^{2-4)}$. しかしながら， これらの審美性や装着感を最優先した義歯設計が従来か らの設計原則を遵守せずに先行しているという懸念もあ り，補経学的根拠がそしいまま製作されているのが実情 である。

義歯設計は，歯科医師自身が行うものである．歯科医 師か設定したレストの数とその配置によって支台歯間線 が導かれ，機能時における義歯の動態が想定される。義 歯は，機能力を残存歯と欠損部顎堤にできるかぎり均等 に配分させることが重要であり，残存歯に強く支持，把 持を求めた設計が求められている ${ }^{5-9)}$. しかしながら, ノンクラスプデンチャーにおいては，金属クラスプのみ ならずレストを設置しないメタルレスの設計も行われて おり，補綴学のセオリーからは大きく逸脱しているもの と考えられる.

そこで，本研究はノンクラスプデンチャーの適切な設 計指針の策定を目指し，ノンクラスプデンチャーにおけ る金属レストの有無が義歯床下粘膜の負担圧分布に及ぼ す影響を明らかにするため，圧力センサーを設置した金 型シミュレーション模型を用いて実験的検討を行った。

\section{II. 材料と方法}

\section{1. シミュレーション模型}

シミュレーション模型は下顎片側性中間欠損を想定 し，支台歯，欠損部顎堤をそれぞれ単純化した三次元構 造体とし，18-8 ステンレス鋼により製作した。シミュ レーション模型の支台歯である犬歯遠心相当部および第 二大臼歯近心相当部には, 縦 $3.0 \mathrm{~mm}$, 横 $3.0 \mathrm{~mm}$, 深さ $3.0 \mathrm{~mm}$ のレストシートを設定した。 また支台歯 の高さは $6.0 \mathrm{~mm}$ とした。 欠損部顎堤の形態は, 擬似

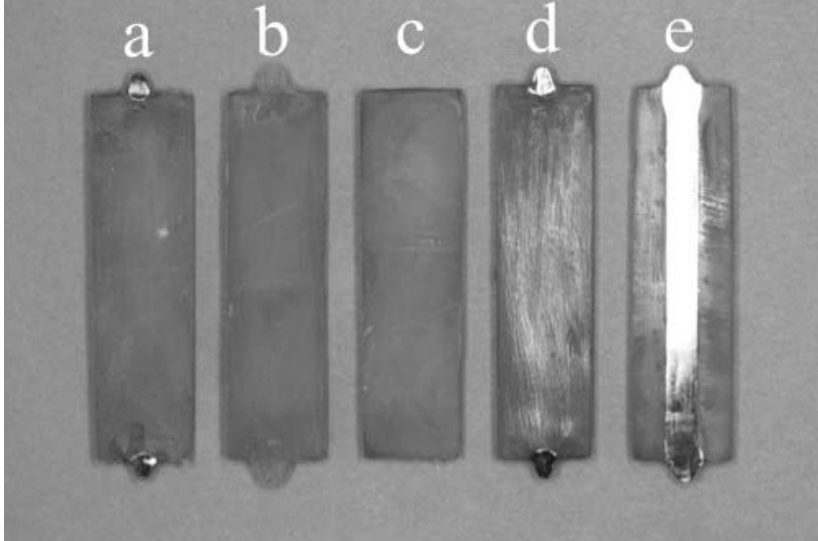

図 2 Experimental dentures

a: Nonmetal clasp denture with metal rests b: Nonmetal clasp denture with thermoplastic resin rests

c: Nonmetal clasp denture without rests $\mathrm{d}$ : Acrylic resin denture with metal rests e: Metal structural denture with metal rests 実験義歯

$\mathrm{a} ：$ 金属レスト NCD

$\mathrm{b}:$ 樹脂レスト NCD

c：レストなし NCD

$\mathrm{d}:$ 金属レスト ARD

$\mathrm{e}$ ：金属レスト MBD

粘膜を介して圧力センサーが均一な面で実験義歯と接触 するよう平板状とし，第一小臼歯，第二小臼歯，第一大 臼歯相当部の 3 力所に, 直径 $6.0 \mathrm{~mm}$ の超小型圧力七 ンサー (PS-10 KD，共和電業，東京，日本）を設置し た. 以下，第一小臼歯相当部のセンサーを $1 \mathrm{ch}$ とし， 第二小臼歯相当部，第一大臼歯相当部のセンサーの順に $2 \mathrm{ch}, 3 \mathrm{ch}$ と表示する (図 1).

擬似粘膜は，適合診査用シリコーン印象材（フィット チェッカー，GC，東京，日本）を重量比 6 対 1 に練和 し，注意深く気泡を混入しないよう実験義歯床下に介在 させ，シミュレーション模型に圧接し擬似粘膜とした。 また厚径は菲薄な粘膜を想定し， $0.5 \mathrm{~mm}$ とした。擬 似粘膜は，1 回の測定ごとに交換した。

\section{2 実験義歯の製作}

実験義歯は，金属レスト付きノンクラスプデンチャー （以下，金属レスト NCD)，レストも熱可塑性合成樹脂 で製作したノンクラスプデンチャー（以下，樹脂レスト NCD)，レストを設置しないノンクラスプデンチャー （以下，レストなし NCD）の 3 種類とした。またコン トロールとして，金属レスト付きアクリルレジン床義歯 （以下，金属レスト ARD）および二重構造フレームワー クをコバルトクロム合金にて製作した金属レスト付き金 

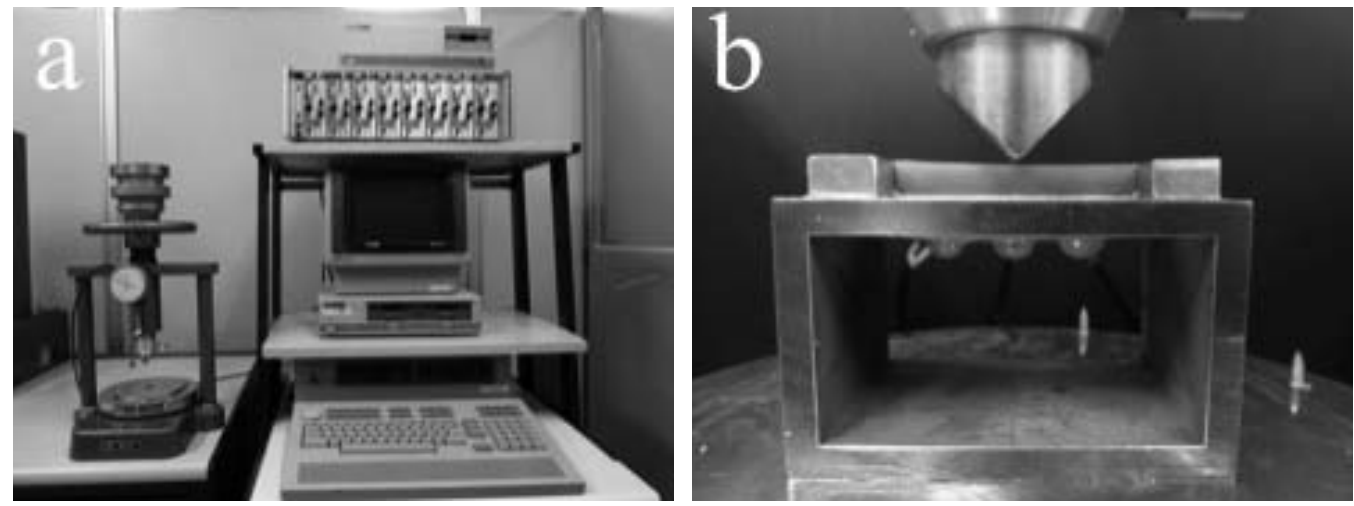

図 3 Measuring device and system

a: Constant load-press machine, dynamic strain amplifier, analog-to-digital converter and a personal computer $\mathrm{b}$ : A vertical load to the experimental denture

測定装置および計測システム

$\mathrm{a}$ ：定荷重試験器，動ひずみ測定器，A/D コンバー夕およびパーソナルコンピュータ

b : 実験義歯に対する垂直荷重

属構造義歯（以下，金属レスト MBD）の 2 種類を製作 し，実験に使用した。計 5 種類の実験義歯は余剰部分 を削合した後，シミュレーション模型に適合するようエ メリー紙\#80～\#400 まで順次, 研磨成形した(図 2).

1）金属レスト NCD

シミュレーション模型に設定した支台歯上のレスト シートに適合するように, $12 \%$ 金銀パラジウム合金 （キャストウェル M.C., GC，東京，日本）を用い金属レ ストを製作した。鉤脚の厚さは $1.0 \mathrm{~mm}$ とし，レスト の長さ，幅，高さは支台歯に設定したレストシートに合 わせ，それぞれ $3.0 \mathrm{~mm}$ とし，ワックスパターンを製 作したのち鋳造を行つた。鋳造後の金属レストをシミュ レーション模型から製作した石膏模型（ニューフジロッ ク，GC，東京，日本）に適合させ義歯床部分をワック スアップした。 なお，測定時に圧接する擬似粘膜のスペー スを確保するため, 印象時に厚さ $0.5 \mathrm{~mm}$ のアクリル 板を介在させた状態で石膏模型を製作した。スプルーイ ングした板状のワックスを埋没後，メーカー指示に従い 射出成形機（MIS-II，i-cast，東京，日本）にてポリア ミド系合成樹脂(バルプラスト,バルプラストジャパン, 東京，日本）を射出成形した。

2）樹脂レスト NCD

シミュレーション模型から製作した石膏模型に義歯床 部分およびレスト部分をワックスアップし，スプルーイ ング，埋没を行った後，メーカー指示に従いポリアミド 系合成樹脂を射出成形した。

3）レストなし NCD

レストも熱可塑性合成樹脂で製作したノンクラスプデ ンチャーの製作と同様にポリアミド系合成樹脂を射出成
形し，レスト部分を切断することによってレストを設置 しないノンクラスプデンチャー試料とした。

4）金属レスト ARD

金属レスト NCD と同様に製作した金属レストを石膏 模型に適合させ，義歯床部分をワックスアップし，加熱 重合レジン（アクロン，GC，東京，日本）を用いて埋 没，填入，湿式重合 $\left(70^{\circ} \mathrm{C}, 12\right.$ 時間) を行った。

5）金属レスト MBD

二重構造フレームワークは，シミュレーション模型か ら製作した耐火模型上にワックスアップし，パターンを 製作した。 パターンはリン酸塩系埋没材 (ヘラベスト $\mathrm{M}$ ，ヘレウスクルッァージャパン，大阪，日本）を用い て埋没し，焼却後，コバルトクロム合金（ウイジル， Dentsply，東京，日本）を真空圧迫鋳造機（へラキャ スト $\mathrm{iQ}$ ，ヘレウスクルッァージャパン，大阪，日本）に て鋳造を行った.完成したフレームワークは, 形態修正, 研磨後，石亳模型に適合させ，常温重合レジン（パラエ クスプレス, ヘレウスクルツァージャパン，大阪，日本） を重合し完成した。なお，重合に際しては，乾式加圧釜 (ベストプレッシャー 3 ，東邦歯科産業，埼玉，日本）を 用い $0.49 \mathrm{MPa}\left(5 \mathrm{kgf} / \mathrm{cm}^{2}\right)$ で加圧した。

\section{3. 測定方法および計測システム}

実験義歯をシミュレーション模型の定位置に設置し, 定荷重圧縮試験機改良型（セイキ，東京，日本）を用い て荷重試験を行った。荷重用器具には真鍮製の楔形ス夕 イラスを使用し，第二小臼歯相当部直上から $49.0 \mathrm{~N}$ の 荷重を加えた. 荷重部には小型荷重変換器(LM 20 KAA 1，共和電業，東京，日本）およびダイアルゲージ型変 


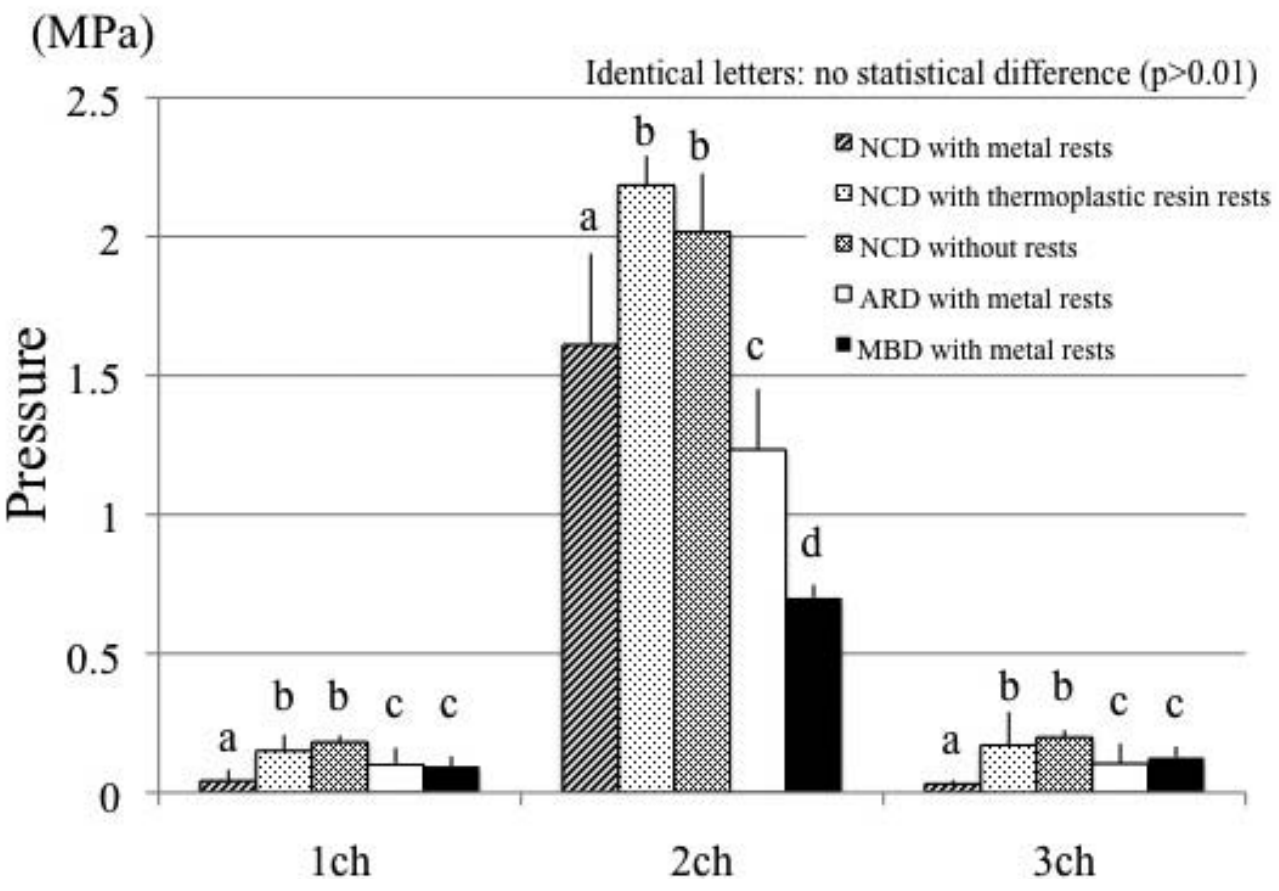

図 4 Pressure distribution to soft tissue 義歯床下粘膜の負担圧分布

位変換器（DT-20，共和電業，東京，日本）を設置し， 荷重時の義歯床下粘膜の負担圧分布および垂直的変位量 を同時測定した (図 3)。測定は，1 個の実験義歯につ き5 回ずつ行った。

計測システムは, 圧力センサー, 荷重変換器および変 位変換器の抵抗変化により生じる出力電圧を動ひずみ測 定器 (DPM 613 B, 共和電業, 東京, 日本) で増幅し, A/D コンバータ (PS-9351，TEAC，東京，日本) で 14 ビットデジタル変換後, パーソナルコンピュータ (PS 9000 Model 310，日本 HP，東京，日本)に取り込み， 演算および記録を行った (図 3)。各実験義歯につき 5 回の測定データの平均值を義歯床下粘膜の負担圧および 垂直的変位量とした。得られたデー夕の統計処理は一元 配置分散分析後, Tukey の多重比較を行い，危険率 $1 \%$ で有意差を判定した。

\section{III. 結 果}

第二小臼歯相当部直上から荷重を加えた時の義歯床下 粘膜の負担圧分布を図 4 に示す. 5 種類の義歯は義歯 床用材料の相違にかかわらず，第二小臼歯相当部の負担 圧 (2 ch) が 0.67〜2.19 MPa と大きな負担圧を示し, 第一小臼歯相当部および第一大臼歯相当部 $(1,3 \mathrm{ch})$ では，ほぼ同様に 0.03〜0.20 MPa の小さな負担圧で あり，部位間で大きな相違が認められた。
第二小臼歯相当部の負担圧 $(2 \mathrm{ch})$ は， NCD に着目 してみると，樹脂レストが，2.19 MPa と最も大きな負 担圧を示し, 次いでレストなし, 金属レストの順であり, 金属レストの設置が最も小さな負担圧を示した。一方， 同形態の金属レストを付与した ARD と MBD はさらに 小さな值であり，特に MBD は $0.67 \mathrm{MPa}$ と最も低い 負担圧を示した。統計的には樹脂レスト NCD とレスト なし NCD との間に有意差は認められなかったが（p> 0.01)，それ以外のすべての試料間において有意差が認 められた $(p<0.01)$.

第一小臼歯相当部の負担圧 $(1 \mathrm{ch})$ は，レストなし NCD の負担圧が $0.22 \mathrm{MPa}$ と最も大きく, 樹脂レスト

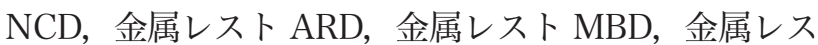
ト NCD の順で負担圧は減少した。第一大臼歯相当部の 負担圧 $(3 \mathrm{ch})$ も $1 \mathrm{ch}$ と同様に，レストなし NCD の 負担圧が最も大きく，樹脂レスト NCD，金属レスト

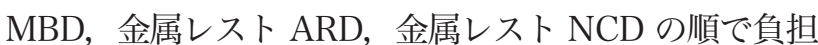
圧は減少した。 $1 \mathrm{ch}$ および $3 \mathrm{ch}$ ともに，樹脂レスト NCD，レストなし NCD 間と，金属レスト ARD，金属 レスト MBD 以外の実験義歯間において有意差が認め られた $(\mathrm{p}<0.01)$.

図 5 に第二小臼歯相当部における実験義歯の垂直的 変位量を示す。NCD 間においては金属レストが 103.5 $\mu \mathrm{m}$ と最も大きく，以下樹脂製レスト，レストなしの順 に減少した。一方，同形態の金属レストを付与した ARD 


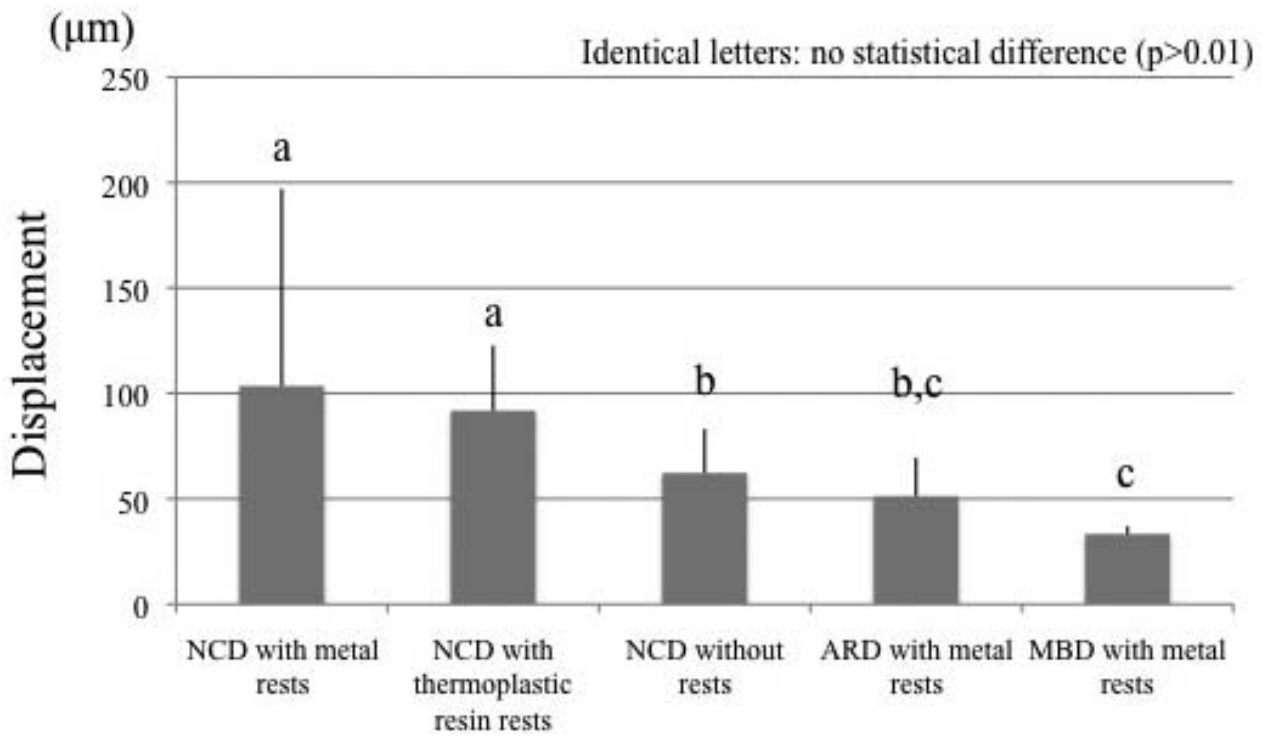

図 5 Vertical displacement of experimental dentures

実験義歯の垂直的変位量

と MBD は NCD より小さな変位量を示し，特に MBD は同タイプ NCD の約 1/3 の変位量であった。統計的 には金属レスト MBD，金属レスト NCD，樹脂 NCD 間，金属レスト ARD，レストなし NCD および金属レ ストMBD 間のそれぞれに有意差は認めなかったが， それ以外の実験義歯間では有意差が認められた $(p<$ $0.01)$.

\section{IV. 考 察}

被圧変位量の大きく異なる残存歯と顎堤粘膜により支 持される部分床義歯は, 双方に対して適切に咬合力を配 分することが極めて重要である. 1950 年頃までの義歯 設計では，強固な歯根膜支持は支台歯に支障があるもの として緩圧型の設計が多く行われてきた。これに対し 1962 年 Rehm ${ }^{5)}$ は，支台歯と義歯床とは強固に連結し ても支障がないとする，いわゆる非緩圧型設計の適否を 検討した。 それ以来, Körber ${ }^{6)}$, Baer $~^{7)}$ が実験的に, Gaerny $^{8)}$, Eichner ${ }^{9)}$ らが臨床的にその妥当性を検討 し，リジッドサポートと呼ばれた支持様式が現在の部分 床義歯設計原則の中核をなしている，特にレストが重要 な役割を果たしていると考えられ，Sato ら ${ }^{10)}$ ，Stern $ら^{11)}$, Cecconi ${ }^{12)}$ は，レストの配置，設置数の相違に よるレストの重要性を報告した。本研究においては，レ ストの有無および材質の相違が負担圧分布に及ぼす影響 の度合いを明確にするため，レストシートの深さを 3.0 $\mathrm{mm}$ と設定した。

一方，義歯床用材料には剛性が必要である．Regli
$ら^{13,14)}$ は，金属床義歯とアクリルレジン床義歯におい て義歯内部に発生するひずみを検討し，金属床義歯の剛 性はアクリルレジン床義歯の約 8.5 倍と報告した。ま た，阿部ら ${ }^{15)}$ は，義歯床の剛性をさらに高めるために 従来のスケルトンとメタルティースを支柱で連結した二 重構造設計を考案した。 以来，当講座で行われた構造設 計に関する一連の研究により，金属構造義歯が残存諸組 織に及ぼす負の影響は最小限であることを実証し た ${ }^{16-21)}$. 本研究では, ノンクラスプデンチャーにおけ るレストの有効性および義歯床の過剩な弾性による影響 を検証するため，アクリルレジン床義歯および金属構造 義歯をコントロールとして, 実験的検討を行った.なお， 本研究ではアクリルレジン床義歯には加熱重合レジン を，金属構造義歯には技工上の問題から常温重合レジン を使用した。既報の研究結果 ${ }^{16-21)}$ より，使用レジンが 異なっていても両義歯の剛性には明らかな相違があり, 金属構造義歯を比較試料に加えることで，義歯床の剛性 による影響が明確になったと思われる。

今日，わか国で厚生労働省から薬事法による製造販売 が正式に認証されている熱可塑性合成樹脂は，ポリアミ ド系，ポリカーボネート系，ポリエチレンテレフタレー 卜系，アクリル系の 4 種類である. なかでもポリアミ ド系は認可が早かつたことから ${ }^{2)}$, 最も一般臨床で用い られていると推測される ${ }^{22)}$. Takabayashi ${ }^{23)}$ の報告に よれば，ポリアミド系は $826.2 \mathrm{~N} / \mathrm{mm}^{2}$ とアクリルレ ジンに比較して約 3.5 倍の熱可塑性合成樹脂のなかで 最も高い弾性を有している，また，曲げ強さにおいても アクリルレジンの約 2 倍を示し，熱可塑性合成樹脂の 
なかでも最大である，本研究では，一般臨床において最 も需要が大きく，ノンクラスプデンチャーの最大の利点 である高い弾性を有している，という二つの理由からポ リアミド系合製樹脂を実験材料として選択した。

第二小臼歯相当部 $(2 \mathrm{ch})$ のノンクラスプデンチャー の負担圧が，コントロール群に対して有意に大きな負担 圧を示したことから, 中間欠損においても荷重部位の負 担圧分布はアクリルレジン床義歯の約 1.5〜2 倍, 金属 構造義歯の約 2〜3 倍増大することが判明した. 3 種類 の異なったレストを設計したノンクラスプデンチャーの なかで，レストなし NCD および樹脂レスト NCD が最 も大きな負担圧を示したが，金属レストを付与すること で負担圧が減少した。このことより，ノンクラスプデン チャーの設計に際しては，金属レストの設置が義歯床下 粘膜への負担圧軽減に必須であることが示唆された。樹 脂レスト NCD とレストなし NCD において有意差が認 められなかったものの，レストなし NCD の第二小臼歯 相当部の負担圧がやや小さい傾向にあった理由として, 荷重位置の影響があげられる，本研究では，荷重点を第 二小臼歯相当部直上の一点に設定したことにより，樹脂 レスト NCD では $2 \mathrm{ch}$ 部のみの義歯床が沈下し, レス トなし NCD は実験義歯全体が沈下するため $1 \mathrm{ch}, 3$ ch 部に負担圧が分散されたものと考えられる.

義歯床の垂直的変位量は，負担圧の大きさと高い相関 があると考えられる。しかしながら，本研究結果ではや や異なった結果を示した。レストなし NCD が金属レス

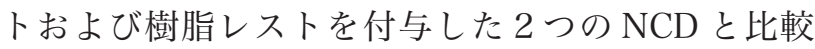
し, 小さな垂直的変位量を示したのは, レストなし NCD では義歯床の変形が少なく全体の沈下が生じたため負担 圧も分散した結果と考えられる。樹脂レスト NCD が, 金属レスト NCD よりも小さな変位量を示したのは，樹 脂レストはレスト自体の剛性が低いため, 変形により 1 ch，3 ch 部においても沈下し，レストなし NCD と同 様に負担圧が分散したと考えられる。これらの結果はレ ストなし NCD と樹脂レスト NCD が，金属 NCD に比 較して， $1 \mathrm{ch} ， 3 \mathrm{ch}$ 部の負担圧分布が有意に高くなっ ていることからも肯定される。したがって，本荷重条件 においては，ノンクラスプデンチャーに金属レストを付 与することにより粘膜負担圧の軽減は認められたもの の，ノンクラスプデンチャー自体のたわみを著しく軽減 することはできなかった。この結果からも症例選択に留 意するだけでなく，メタルフレームワークを応用するな どノンクラスプデンチャーの義歯床部分の剛性を向上さ せる必要があることが示唆された。

以上のことから，ノンクラスプデンチャーにおける負 担圧分布は，従来のアクリルレジン床義歯や金属構造義
歯に比較し粘膜負担が大きくなりやすく，症例選択には 十分な配慮が必要であると考えられる。また，ノンクラ スプデンチャーにおいても金属レストを付与することに より負担圧は軽減したことから，臨床上やむなくノンク ラスプデンチャーを適応する際には，金属アレルギーな どの制約がなければ金属レストの付与が不可欠であるこ とが示唆された。

\section{V. 結 論}

本研究においてノンクンラスプデンチャーに使用した 材料であるポリアミド系熱可塑性合成樹脂は，大きな弾 性を有することから荷重時に義歯床に大きな変形を生 じ，アクリルレジン床や金属構造義歯と比較して義歯床 下粘膜の負担圧が有意に大きくなると考えられる。この 結果から，ノンクラスプデンチャーを臨床応用する場合 には，適応症例の選択に十分な配慮が必要であることが 示唆された. また,ノンクラスプデンチャーにおいても, 金属レストを併用することで負担圧を軽減できる可能性 か明らかになったことから，義歯床下粘膜の負担圧軽減 のために，金属レストの設置は不可欠であることが示唆 された。

謝辞

本研究の一部は文部科学省, 日本学術振興会科学研究費補 助金（若手研究 B 21791923）によって遂行された。

\section{文献}

1）長谷川正康。江戸の入れ歯師たち。東京 :一世出版 ; 2010,23-25.

2）細井紀雄。ノンクラスプデンチャー．DE 2009; 168: 14.

3） 大久保力廣，細井紀雄，高林洋太，小野寺進二，石川千 恵子, 渡邊 誠。実践歯学ライブラリーノンクラスプデ ンチャーの特徴と臨床応用. デンタルダイヤモンド 2009;34 (12) : 22-44.

4） 大久保力廣。ポリアミド系樹脂製ノンクラスプデンチ ヤ一の現在一欠損補綴の一選択肢となり得るか。歯科評 論 2010;70 (10)：51-58.

5) Rehm H. Biophysikalischer Beitrag zur Problematik starr abgestützter Freiend-prothesen. Dtsch zahnärztlZ 1962; 17:963-965.

6) Körber KH, Heners M. Fundermentals of in remaining dentition rigidly supported partial prosthesesinstructions for design. ZWR 1973; 82: 558-559.

7) Baer O. Stability of partial dentures. SSO Schweiz Monatsschr Zahnheilkd 1969; 79: 1143-1157.

8) Gaerny A. Examples of fixed removable prostheses 
for extreme cases of jaw defects. Quintessence 1969; 20:75-77.

9) Eichner K. Handatlas der zahnärztlichen Prothetik. Carl Hanser Verlag 1962; 32: 131-132.

10) Sato Y, Hosokawa R, Tsuga K, Kubo T. The effects of buccolingual width and position of occlusal rest seats on load transmission to the abutments for toothsupported removable partial dentures. Int J Prosthodont 2001; 14:340-343.

11) Stern MA, Brudvik JS, Frank RP. Clinical evalution of removable partial denture rest seat adaptation. J Prosthet Dent 2001; 53:658-662.

12) Cecconi BT. Effect of rest design on transmission of forces to abutment teeth. J Prosthet Dent 1974; 32: 141-151.

13) Regli CP, Gaskill HL. Denture base deformation during function. J Prosthet Dent 1954; 4: 548-554.

14) Regli CP, Kydd WL. A preliminary study of the lateral deformation of metal base dentures in relation to plastic base denture. J Prosthet Dent 1953; 3: 326330.

15）阿部 實，宮田孝義，尾花甚一，咬合診断・治療のため にすれ違い咬合の症例から，補綴臨床 1984 ; 別冊 : 154-163.

16）三山善也，宮田孝義，尾花甚一，歯科技工アトラス 6 . 東京：医歯薬出版；1984, 234-255.
17）阿部 實，宮田孝義，尾花甚一ＲPD 補綴の考元方と 実際4)、デンタルダイヤモンド 1986; 11(4) : 44-47.

18）宮田孝義 診断と治療像を探る 回復した機能を長期に 保つために。補綴臨床 1989 ; 別冊 : 97-112.

19）大久保力廣. 義歯の構造設計に関する実験的検討。補綴 誌 1989; 33: 1273-1287.

20）鈴木恭典。義歯の構造が負担圧配分に及ぼす影響に関す る実験的検討。補綴誌 1992;36: 1072-1086.

21）鈴木恭典，大久保力廣，栗原大介，中山 昇，青木孝幸， 花谷重守ほか．義歯構造の相違が支台歯と顎堤粘膜の負 担圧分布に及ぼす影響について : 支台歯が異なる場合. 補綴誌 1996; 40:512-523.

22）鈴木達也，新保秀仁，北野展久，佐藤 薪，川井善之, 神吉ゆかりほか. 弾性熱可塑性合成樹脂義歯（ノンクラ スプデンチャー) のアンケート調査. 日補綴会誌 2011; 3 (120 回特別号) : 132.

23) Takabayashi Y. Characteristics of denture thermoplastic resins for non-metal clasp dentures. Dent Mater J 2010;29:353-361.

著者連絡先 : 廣田 正嗣

T230-8501

神奈川県横浜市鶴見区鶴見 2-1-3

Tel: 045-581-1001（内線 8421）

Fax: 045-573-9599

E-mail:hirota-masatsugu@tsurumi-u.ac.jp 


\title{
Influence of Metal Rest in a Nonmetal Clasp Denture on Pressure Distribution to Soft Tissue
}

\author{
Masatsugu Hirota, DMD, Hidemasa Shimpo, DMD, PhD, \\ Yasunori Suzuki, DMD, PhD and Chikahiro Ohkubo, DMD, PhD \\ Department of Removable Prosthodontics, Tsurumi University School of Dental Medicine
}

Ann Jpn Prosthodont Soc 4: 193-200, 2012

\section{ABSTRACT}

Purpose: Nonmetal clasp dentures have been used recently in dental treatment because thermoplastic resins have particular elasticity that allows them to be retained without metal clasps. These nonmetal clasp dentures have often been designed to be especially aesthetic by using only thermoplastic resins without occlusal rests. The purpose of this study was to examine the influence of metal rests in nonmetal clasp dentures on the pressure distribution to the soft tissue.

Methods: Three pressure sensors were seated on a model simulating mandibular unilateral bounded saddles. Three types of experimental dentures were fabricated on a simulation model: a nonmetal clasp denture with a metal rest, a nonmetal clasp denture with a thermoplastic resin rest, a nonmetal clasp denture without a rest, and two types of control dentures (acrylic resin denture with a metal rest and metal structural denture with a metal rest). Silicone impression material was injected to simulate soft tissue; the pressure distribution during displacement of the soft tissue by the denture was measured using 49.0 N loading. The data obtained $(n=5)$ were analyzed by one-way ANOVA and Tukey's multiple comparisons test $(\alpha=0.01)$.

Results: Statistically significant differences were noted among the five types of dentures. The pressure distribution of the metal structural denture was the lowest, and the pressure distribution of the nonmetal clasp denture with a thermoplastic resin rest was highest. By using a metal rest, we found that pressure was reduced in the nonmetal clasp dentures $(\mathrm{p}<0.01)$.

Conclusions: The above findings indicated that a metal rest should be used for nonmetal clasp dentures to increase pressure on the soft tissue.

\section{Key words}

nonmetal clasp denture, thermoplastic resin, pressure distribution, rest, metal structural denture 